\title{
The Use of Direct Genetic Markers K-Casein and Dgat1, Involved in Milk Production Characteristics
}

\author{
Viorica Coșier $^{11}$, Emil COMȘA ${ }^{1)}$, Radu CONSTANTINESCU ${ }^{1) *}$ \\ 1) Department of Fundamental Sciences and Biotechnologies; University of Agricultural Sciences and \\ Veterinary Medicine of Cluj-Napoca, 3-5 Manastur Street, 400372, Cluj-Napoca, Romania \\ *Corresponding author, e-mail: constantinescu.raduusamv@yahoo.com
}

Bulletin UASVM Animal Science and Biotechnologies 72(2) / 2015

Print ISSN 1843-5262; Electronic ISSN 1843-536X

DOI:10.15835/buasvmen-asb:11551

\begin{abstract}
Application of molecular markers for improved production relies on the ability to genotype individuals for specific genetic loci and to find the significant association between DNA polymorphism and important economic traits. Milk yield, milk composition, fat \%, protein \%, total solids and solids-non-fat are the most important characteristics in diary industry. Effects of K-casein and DGAT1 genes have been shown to be involved in the genetic determinism of these characteristics in cattle. The present study seeks a non-conservative substitution K232A (lysine by alanine) in the DGAT1 gene and for a point mutation, in a $350 \mathrm{bp}$ fragment of kCN gene (exon IV), which distinguishes between the A from $B$ alleles, the latter being desirable for cheese manufacturing. The genetic variation on these two loci was estimated in two cattle populations with different origins, in view of future studies to determine the effect of single gene and interaction effect of genotypes on milk yield and milk composition.
\end{abstract}

Keywords: $k$-casein, DGAT1, milk production characteristics

\section{INTRODUCTION}

Among the multiple strategies to increase milk yield and milk production characteristics, MAS together with traditional selection methods can be the most effective for complex traits, improving accuracy, reducing generation interval and accelerating genetic progress (Dekkers, 2004). Over $90 \%$ of milk proteins belong to the caseins that are important in cheese manufacturing. In the $\mathrm{kCN}$ gene, located on BTA 6, nine allelic variants have been described. A and B alleles are more frequently present in the majority of European cattle breeds. The extensive association studies performed until now have shown important roles of $B$ allele in the stabilisation of milk micelles, cheese production and also in milk composition. The DGAT1 gene located on BTA 14 encodes the enzyme acyl CoA: diacylglycerol-acyltransferase, which plays a fundamental role in higher eukaryotes, in the synthesis of triglyceride by catalysing the reaction of diacylglycerol and fatty acids (Cases et al.,
1998). Both genes have been shown to have strong associations with milk production characteristics in different cattle breeds (Molee et al., 2012). Therefore, it is possible to use these genes as gene markers in selection programmes.

\section{AIMS AND OBJECTIVES}

The objective of this study was to identify a non-conservative substitution of lysine by alanine in the DGAT1gene (position 10433 and 10434, $8^{\text {th }}$ exon) and also for Hinfl polymorphism in the $4^{\text {th }}$ exon of k-casein gene, and to determine genetic variation in these polymorphic loci. The studies were conducted in two cattle breeds, German Holstein $(\mathrm{N}=46)$ and Angus $(\mathrm{N}=19)$, originating from 3 farms.

\section{MATERIALS AND METHODS}

To test the presence of K232A polymorphism in DGAT1 gene, recognised by CfrI enzyme and the Hinfl polymorphism in the $4^{\text {th }}$ exon of k-casein gene, 
Tab. 1. Distribution of the observed allele frequencies for DGAT1 and K-casein loci in both Holstein and Angus breeds; Chi square test, Pvalue and significance according to Hardy Weinberg equilibrium; observed (Ho) and expected (He) heterozygosity values for the fixation indexes (Fis; Fit and Fst)

\begin{tabular}{|c|c|c|c|c|c|c|c|c|c|c|c|c|}
\hline Locus & Allele $/ \mathrm{n}$ & Holstein & Angus & ChiSq & $\mathrm{P} /$ Signif & $\mathrm{Ne}$ & Ho & $\mathrm{He}$ & $\mathrm{F}$ & Fis & Fit & Fst \\
\hline \multirow[t]{2}{*}{ DGAT1 } & $\mathbf{K}$ & 0.533 & 0.842 & $5.751^{\mathrm{a}}$ & $0.016^{*}$ & $1.992^{\mathrm{a}}$ & $0.674^{\mathrm{a}}$ & $0.498^{\mathrm{a}}$ & $-0.354^{a}$ & \multirow[t]{2}{*}{-0.309} & \multirow[t]{2}{*}{-0.084} & \multirow[t]{2}{*}{0.172} \\
\hline & A & 0.467 & 0.158 & $0.668^{\mathrm{b}}$ & $0.414^{\mathrm{ns}}$ & $1.362^{\mathrm{b}}$ & $0.316^{\mathrm{b}}$ & $0.266^{\mathrm{b}}$ & $-0.187^{b}$ & & & \\
\hline \multirow[t]{2}{*}{ K-casein } & $\mathbf{A}$ & 0.652 & 0.158 & $2.504^{\mathrm{a}}$ & $0.114^{\mathrm{ns}}$ & $1.830^{\mathrm{a}}$ & $0.348^{\mathrm{a}}$ & $0.454^{\mathrm{a}}$ & $0.233^{\mathrm{a}}$ & \multirow[t]{2}{*}{0.167} & \multirow[t]{2}{*}{0.472} & \multirow[t]{2}{*}{0.367} \\
\hline & B & 0.348 & 0.842 & $0.668^{\mathrm{b}}$ & $0.414^{\mathrm{ns}}$ & $1.362^{\mathrm{b}}$ & $0.316^{\mathrm{b}}$ & $0.266^{\mathrm{b}}$ & $-0.187^{b}$ & & & \\
\hline
\end{tabular}

the PCR-RFLP technique was used. The DNA was extracted from blood samples and specific pairs of primers were used to amplify two fragments of these genes (Kaupe et al, 2004; Medrano et al., 1990). The PCR reaction was performed in $25 \mu \mathrm{l}$ final volume (12.5 $\mu \mathrm{l}$ My Taq Master mix (Bioline), $10 \mathrm{mM}$ each primer and $8.5 \mu \mathrm{l}$ PCR water). In the RFLP assay, Hinfl and CfrI restriction enzymes were used to recognise specific polymorphisms in the $350 \mathrm{bp}$ PCR fragment of K-casein gene and in the $411 \mathrm{bp}$ fragment of DGAT1 gene, respectively. Digestion product sizes were, on DGAT1: $411 \mathrm{bp}$ (KK); 411; 208; 203 bp (KA) and 208; 203 bp (AA) while in the k-casein fragment they were: $132 / 134$ and $84 \mathrm{bp}(\mathrm{AA}) ; 266 ; 132 / 134$ and $84 \mathrm{bp}(\mathrm{AB})$ and 266 and 84 bp (BB).

\section{RESULTS AND DISCUSSION}

The genetic variation at these two loci was estimated after electrophoresis in 2\% agarose gel, the results were analysed using GenAlEx v6.5 programme, and presented in Table 1.

The results of the genetic structure of populations are in accordance with those reported earlier by other authors (Thaller et al, 2003; Kaupe et al, 2004). Significant differences in chi square test $(\mathrm{P}<0.05)$ were observed only in the case of DGAT1 polymorphism gene in the Holstein breed, but not for the Angus breed, which we attribute to the relatively small number of individuals tested. Negative values for Fis and Fit in DGAT1 marker show a low risk on inbreeding. The Fst values vary between 0.192 on DGAT1 and 0.367 on k-CN, respectively, while medium genetic differentiation between the two subpopulations was detected by an Fst value of 0.279 .

\section{CONCLUSION}

The results could be used to guide association studies between the DGAT1 locus and milk production characteristics, and other possible studies on interaction effects of genotypes on milk yield and milk composition in larger populations.

\section{REFERENCES}

1. Cases S, Smith SJ, Zheng YW, Myers H (1998), Identification of a gene encoding an acyl CoA:diacylglycerol acyltransferase, a key enzyme in triacylglycerol synthesis. Proc. Natl. Acad. Sci. USA. 95: 13018-13023.

2. Dekkers, JMD (2004) Commercial application of markerand gene-assisted selection in livestock: Strategies and lessons, J Anim Sci , 82: E313-E328.

3. Kaupe B, Winter A, Fries R, Erhard G (2004) DGAT1 polymorphisms in Bos taurus and Bos indicus cattle breeds. J Dairy Res, 71 182-187.

4. Medrano JF, Aguilar-Cordova E (1990): Genotyping of bovine k-casein loci following DNA sequence amplification. Biotechnol. 8: 144-146.

5. Molee A. Duanghaklang N, Na-Lampang P (2012), Effects of Acyl-CoA:diacylglycerol acyl transferase 1 (DGAT1) gene on milk production traits in crossbred Holstein dairy cattle. Tropical Animal Health and Production. 44 (4):751755

6. Thaller G, Kramer W, Winter A, Kaupe B, Eehardt G, Fries R (2003). Effects of DGAT1 variants on milk production traits in German cattle breeds. Am Soc Anim Sci 81: 19111918. 